\title{
Todd's paralysis
}

Section Editor

Anne W. McCammon,

MD, FAAN

Amir Adam Tarsha, MS

Correspondence to

Dr. Tarsha:

atarsha@med.miami.edu
Todd's on the railing

with the Hudson rolling grey below.

Yesterday his body seized

as it is wont to do;

today he stands,

mouth full with a bitten tongue,

careful not to look down.

He fears he's trading everything

for a few local headlines

and a dubious paradise.

Fears he's trading it all

to finally sever the wires

that have short circuited

so many times before.

Fears that he'll stand here forever

on the edge of the GW bridge-paralyzed

unable to leap forward or turn back.

He fears he's surrendering

everything:

coffee on the fire escape at dawn,

the entire city rising like steam,

the soft noise of her tossing and turning

as the sun fills his loft—fears he's surrendering

it all:

the looping track of his heart,

the warblers returning to the park,

the tree-lined streets flooding

with rain

with leaves

with snow

with rain again. 


\section{Neurology}

Todd's paralysis

Amir Adam Tarsha

Neurology 2015;85;e129

DOI 10.1212/WNL.0000000000002071

This information is current as of October 26, 2015

Updated Information \&
Services

Subspecialty Collections

Permissions \& Licensing

Reprints including high resolution figures, can be found at: http://n.neurology.org/content/85/17/e129.full

This article, along with others on similar topics, appears in the following collection(s):

\section{All Epilepsy/Seizures}

http://n.neurology.org/cgi/collection/all_epilepsy_seizures Depression

http://n.neurology.org/cgi/collection/depression

Information about reproducing this article in parts (figures,tables) or in its entirety can be found online at:

http://www.neurology.org/about/about_the_journal\#permissions

Information about ordering reprints can be found online:

http://n.neurology.org/subscribers/advertise

Neurology ${ }^{\circledR}$ is the official journal of the American Academy of Neurology. Published continuously since 1951, it is now a weekly with 48 issues per year. Copyright () 2015 American Academy of Neurology. All rights reserved. Print ISSN: 0028-3878. Online ISSN: 1526-632X.

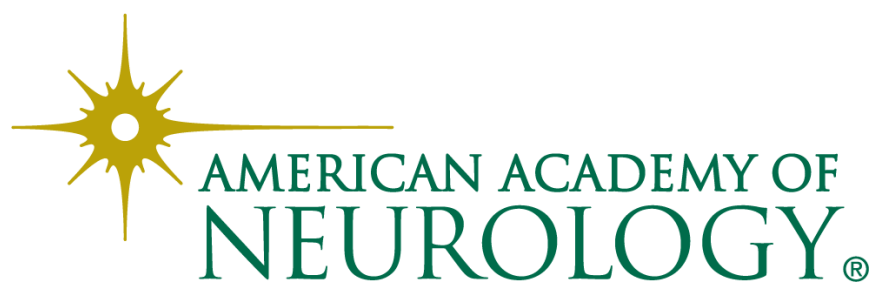

